TITLE:

\title{
A nonhuman primate model of liver fibrosis towards cell therapy for liver cirrhosis(Abstract_要旨)
}

$\operatorname{AUTHOR}(\mathrm{S})$ :

Yasuda, Katsutaro

\section{CITATION:}

Yasuda, Katsutaro. A nonhuman primate model of liver fibrosis towards cell therapy for liver cirrhosis. 京都大学, 2020, 博士 (医学)

ISSUE DATE:

2020-09-23

URL:

https://doi.org/10.14989/doctor.r13371

RIGHT: 


\begin{tabular}{|c|c|c|c|}
\hline & & & \\
\hline & \multicolumn{3}{|c|}{$\begin{array}{l}\text { A nonhuman primate model of liver fibrosis towards cell therapy for } \\
\text { liver cirrhosis（肝硬変に対する細胞療法の確立のための非ヒト霊長類肝線維 } \\
\text { 症モデルの開発） }\end{array}$} \\
\hline \multicolumn{4}{|c|}{ 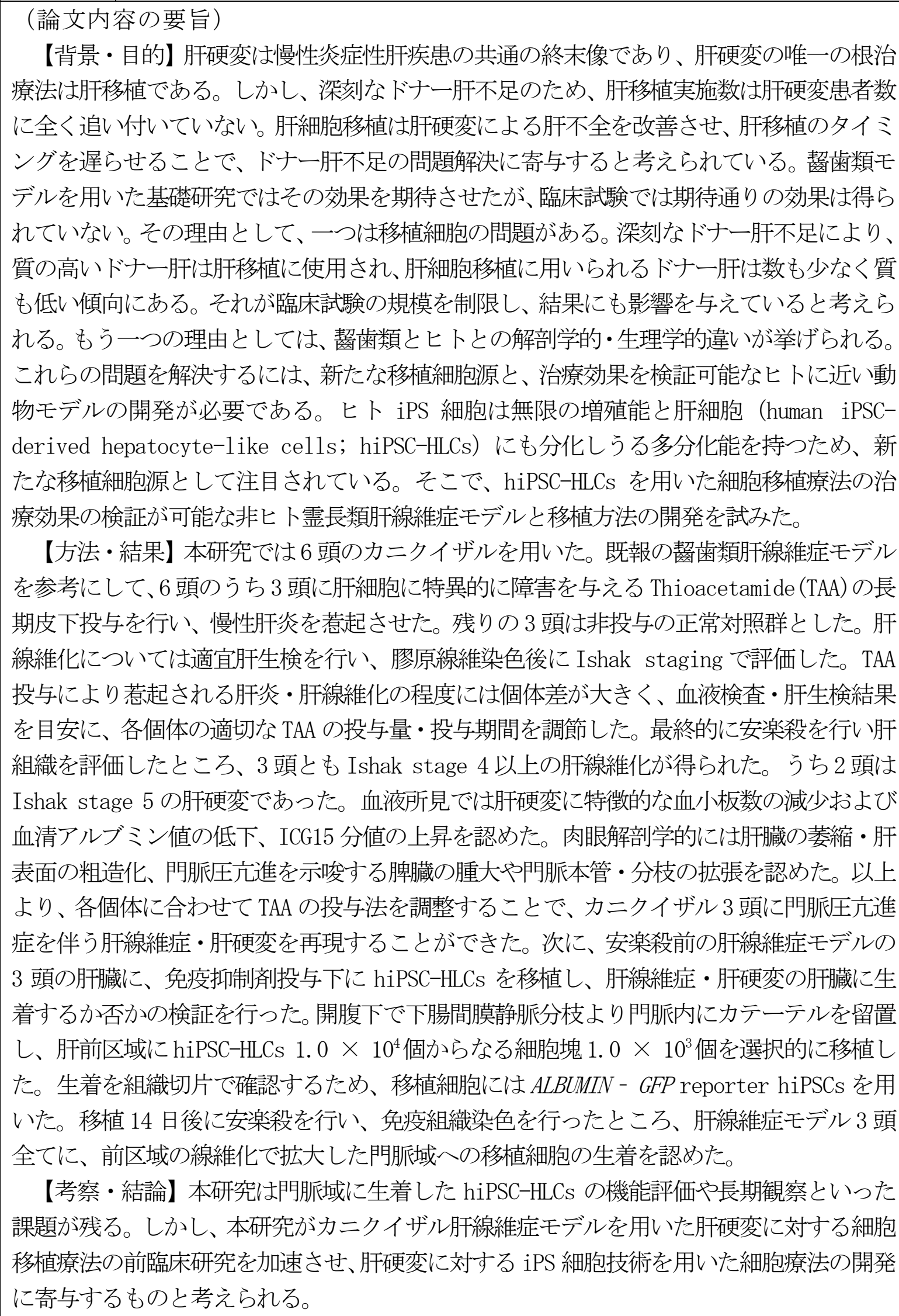 } \\
\hline
\end{tabular}

(論文審査の結果の要旨)

肝移植は肝硬変の唯一の根治療法であるが、深刻なドナ一肝不足の問題が存在する。 iPS 細胞由来肝細胞を用いた細胞移植療法は、この問題の解決に寄与寸ると期待されて いる。本研究は、その実現に向けてヒトと同じ霊長類であるカニクイザルを用いた肝線 維症モデルの樹立と移植方法の確立を目的とした。

血液検査・肝生検による肝障害・肝線維化の評価を適宜行いつつ、投与量・投与期間 を調節してチオアセトアミドをカニクイザルに反復投与することで、投与された 3 頭全 てに Ishak fibrosis score 4 以上の肝線維症、うち 2 頭は Ishak fibrosis score 5 の 肝硬変の再現に成功した。樹立した肝線維症モデルは典型的な肝硬変の血液所見を呈し、 門脈圧え進を示唆する脾腫や門脈系の拡張を伴っていた。続いて、作製したカニクイザ ル肝線維症モデルの下腸間膜静脈分枝より門脈前区域枝に血管カテーテルを進め、免疫 抑制剂投与下にアルブミンレポーターヒト iPS 細胞株より分化誘導した肝細胞を肝前区 域に移植した。移植後 14 日目の肝前区域の組織切片の免疫染色を行い、本移植条件でヒ 卜 iPS 由来肝細胞がカニクイザルの肝線維症・肝硬変の肝臓の門脈域に生着することを 確認した。

以上の研究はカニクイザル肝線維症モデルを用いた前臨床研究を加速させ、肝硬変に 対するヒト iPS 細胞由来肝細胞を用いた細胞療法の実現に寄与するところが多い。 したがって、本論文博士（医学）の学位論文として価值あるものと認める。 なお、本学位授与申請者は、令和 2 年 7 月 16 日実施の論文内容とそれに関連した 試問を受け、合格と認められたものである。 